\title{
Lou, Bawin Dayak, and the Role of Media in Cultural Tourism of West Kutai, East Kalimantan
}

\author{
Laksmi Kusuma Wardani ${ }^{1}$, Ronald Hasudungan Irianto Sitindjak ${ }^{2}$, Poppy F. Nilasari ${ }^{3}$ \\ laksmi@petra.ac.id ${ }^{1}$,ronald_his@petra.ac.id ${ }^{2}$, popie@ petra.ac.id ${ }^{3}$ \\ Interior Design Department, Petra Christian University ${ }^{1,2,3}$
}

\begin{abstract}
Lou is a traditional house of the Benuaq Dayak tribe which represents Dayak human cultural values regarding family and community life. This reasearch is a critical analysis of traditional houses, gender roles, and media in cultural tourism. The paper adopts interpretation methods for data analysis. The data was collected through direct object observation and online media data search. Findings described that Lou Dayak Benuaq has become a touristic art media with Bawin Dayak as a tourist art service. Based on the results of the analysis, cultural artifacts in the form of lou have undergone decentralization. Lou has become a touristic art that has undergone the art of acculturation culture or pseudo-traditional art which contains commercial values that place Bawin Dayak as a cultural charm.
\end{abstract}

Keywords: Bawin Dayak, Lou, Culture, Tourism, Media.

\section{Introduction}

The culture of oral tradition has developed rapidly towards a visual culture due to the development of increasingly advanced and sophisticated technology. The advanced phenomenon of civilization has certainly been influenced by new discoveries to meet human needs. In the past, oral tradition as a medium of communication was carried out from generation to generation through myths and folk stories which later developed into written and visual culture. With the advent of electricity and electronic goods, the visual culture has experienced rapid progress marked by new media today. Through the cable network, even the internet has transformed information such that it could be accessed quickly and unlimitedly. The emergence of a variety of social media has become a means of imaging, which does not necessarily describe the real state of reality. There are several disadvantages of the rise of visual media, audio visual or other social media. Yet, as long as a person's concentration is only on weaknesses, there would be no solution to the imbalance. For this reason, it is necessary to see the positive side of how changes support developmental progress.

Oral traditions concerning the understanding of meanings or cultural values of the past have been transmitted to the public by hearing and from direct viewing of objects, humans and their activities. In understanding the meaning of traditional culture (especially traditional buildings), visual form becomes an important aspect for the delivery of messages for promotions that invite attraction. The media that is developing today offers information needed by consumers with interesting forms that attract charm. The information conveyed can 
be a useful valuable information that can persuade, influence to action, educate, or entertain the audience [1]. In the past, the concept of visual aesthetics emphasized the real experience of seeing objects, i.e: all human senses would undergo an aesthetic experience by presenting themselves in front of objects. When talking about the context of space, the experience of feeling space in real terms was very important in order to conclude whether the space was considered comfortable, safe, humane and cultured. At present, with the development of communication media, a traditional building can be enjoyed without having to be there, while the human spatial experience will always involve all human senses. Ocassionally, the media convey information that is different from the true reality. For this reason, the delivery of messages / information in the media needs to be prudent in accordance with the cultural values of the community.

Lou is a traditional house of the Benuaq Dayak tribe which represents the cultural values of Dayak people in the past. At present, some Lou have been abandoned by their occupants and are only used for traditional ritual activities, while some others are still inhabited by the heirs and descendants of their owners. Today, Lou Dayak Benuaq has been designated as a cultural heritage building by the local government. Lou was used by women known as Bawin Dayak and was used as a living space for her family and community. At present, it has changed its function to become a tourism object. Lou for the Bawin Dayak is a place of protection and security as well as a place to work. The daily activties of Bawin Dayak such as making Ulap Doyo and woven bamboo are part of their cultural activities that are currently used as a medium for tourism promotion. Tourists are often invited to the Lou buildings as the first objects of attraction and the ing activities of Bawin Dayak becomes a performing art for the tourists to enjoy. Based on some of the explanations above, this research aims to discover the role of Lou, Dayak Bawin, and the media in cultural tourism.

\section{Research Methodology}

This research aims to examine the cultural heritage of traditional house buildings and the involvement of women in cultural activities to participate in promoting the cultural wealth of their regions. The data collection method used was direct observation of the traditional houses, interviews with women who live in them, observing the women's activities in preserving culture, and observing building promotions and the women on Instagram media. The approach used was the hermeneutic approach, a method of interpretation or interpretation of contextual meanings, in which the meaning of each entity is determined by the overall context. The analysis used was critical analysis, in which the findings described the role of Lou, Bawin Dayak, and the media in cultural tourism [2].

\section{Discussions}

\subsection{Lou Dayak Benuaq as a Tourist Art Media.}

The traditional house where the Dayaks live is called Lou in the Dayak Benuaq or Lamin language in the Dayak Kutai language (Figure 1). It is a long house built on stilts where ten to thirty householders from one lineage live together under one roof. Lou can get longer along with the increase of new families [3]. In Jempang Subdistrict, West Kutai, there are 
buildings known as Lou Batu Bura, Temenggung Marta, and Taman Jamrud. Lou Temenggung Marta is the oldest lou in Tanjung Isuy. The building was founded in 1928. The building is 130 meters long. However, because there are no inhabitants in the lou today, only 50 meters of the building length still remains. The roof is made of ironwood shingle, the walls and floor are board-shaped. The lou was built as a shelter, gathering, and mediating space because there were often inter-tribal attacks. In addition, traditional ritual ceremonies for the Dayak tribe were carried out there, such as the kuangkay or kwangkey rituals (death ceremonies), beliatn (medical ceremonies), and the tautn (ritual requests to the universe to correct all blessings in the coming years). Over time, human life have undergone changes and transitions. Each family who used to live in the Lou built their own house and left the Lou to live their own main family [4]. Yet, Lou was constructed with a culture of mutual cooperation, a symbol of shared life in harmony, peace, strength and unity [5]. Lou contains the meaning of protecting, guaranteeing a peaceful and harmonious life. Lou was a manifestation of the relationship of the life of the inhabitants with each other, with their nature, and with God. Lou had a very valuable meaning for the community when the building was first constructed. With the abandonment by its occupants, the spirit of life in the lou has disappeared.

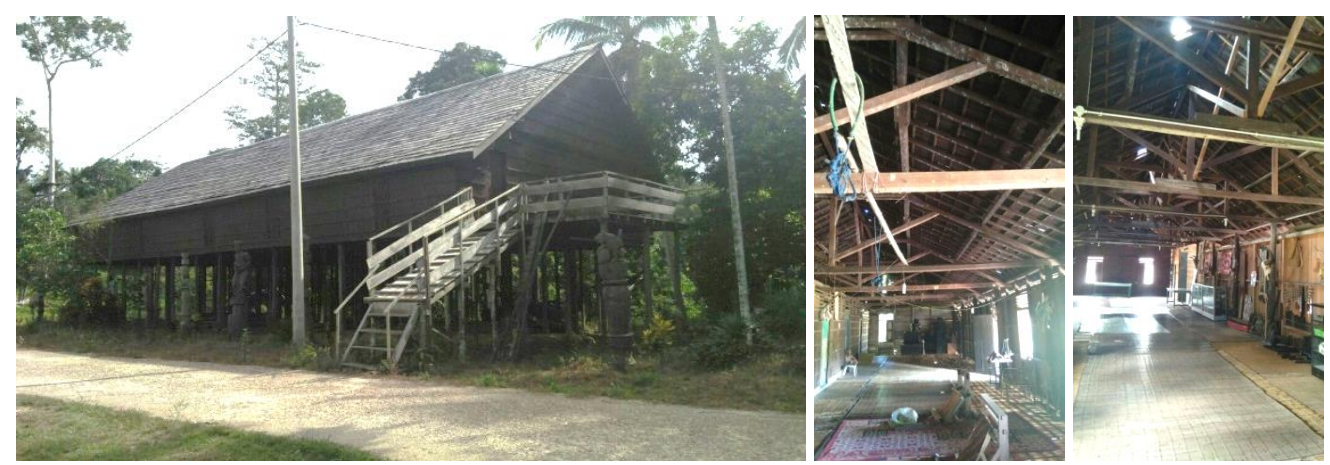

Fig 1. The traditional house of Dayak (Lou)

In connection with this, the regional government have sought to preserve lou as a traditional cultural heritage through revitalization and declaration of Tanjung Isuy lou as a cultural heritage building. The establishment of lou as a cultural heritage building has indirectly changed the function of $l o u$ from a residential home of domestic activities to a museum for education and tourism. Hence, the nature of the house that was once sacred space have changed into a prophane one. Sacred spaces usually instill religious experience to its inhabitants [6]. Today, the house has changed into a prophane one for the purpose of commercializing cultural objects.

Tourists who visit will be greeted with the Ngelewai dance (a welcome dance using scarves), Kuncup Mekar dance (a dance that tells about the process of children growing up and becoming adults), and Gong dance (a symbol of welcoming great guests, or welcoming the birth of a baby, and is a dance that shows a woman's charm for the victory of her heart by a man) [7]. In this case, space (lou building) has become the main mechanism for regulating conditioned social interactions so that it can be enjoyed visually. The physical objects of the building and human activities are the media for display. Lou eventually became part of a tourist art performance and a museum that accommodates activities for touristic purposes (Figure 2). There are five main features of performing arts tour in developing countries: 1) 
imitation of the original, 2) short and compact or miniature of the original, 3) full of variation, 4) stripped of its sacred, magical and symbolic values, and 5) cheap price [8]. With the advent of the art of tourism, the human sensory experience in space has changed. The tourists tend to only get aesthetic experience, not to enjoy it with appreciation of taste. The presentation of the room and the spectacle of the show only provides beautiful and interesting memories for the tourists. However, the presence of art in Kutai Barat enriches the development of cultural arts in Indonesia. This is a positive impact from the presence of the tourism industry in the inlands of the Dayak tribe.
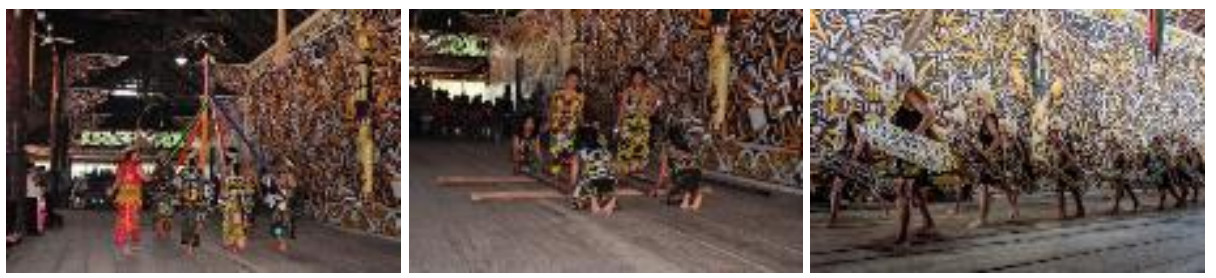

Fig 2. Traditional art performance in lou

\subsection{Dayak Bawin and Cultural Conservation Efforts}

Lou Batu Bura and Tanjung Isuy by the local government are used as the centers for the development of creative economy, especially the development of ulap doyo crafts under the guidance of the East Kalimantan Office of Industry, Trade, Cooperatives and SMEs [9]. Ulap doyo is one of the indigenous cultural identity of the Dayak people which keeps the uniqueness of the material and the production process. Ulap doyo is a kind of weaving art made from doyoleaf fiber (curliglia latifolia) which has strong fiber and is a wild plant of the inlands of Kalimantan. The process is very long, starting with dried leaves, sliced in the direction of the leaf fibers to become fine fibers, which are then woven and rolled to form coarse threads, then given a natural color from the plant, generally brown and red. The red color comes from glinggam fruit, oter wood and londo fruit. Whereas brown is taken from uwar wood color. The process of making doyo repetitions is handed down from generation to generation, especially women. Dayak women began to master the doyo weaving technique since they were young by seeing their mothers working on this activity each day. Scientific transfer was done daily and repeatedly [10]. The Ulap doyo making activity is also a part of the media of attraction for tourists.

A cultural heritage building in the form of a museum, which in its additional event presents a tour show, will always relate to its collection. Lou, which used to be the home of the Dayak Bawin, who daily managed the house and worked at home by making ulap doyo, is demonstrating in life one of the living collections of the museum, the lou. The activity of making ulap doyo is done with diligence, detail and thoroughness by the Bawin Dayak, and hence lou has become a media for the live activities of collection objects.

Women are often used as objects in tourism promotion. Unconsciously, women actually know that they have the attention of others. Hence, women organize themselves in such a way that their bodies are beautiful to look at and are physically perfect. Women are often described as sexual objects [11]. They are rarely portrayed as professionals who can be productive. They are considered important in cultural preservation activities. This seems to be more focused on sexual biological factors as the holder of an important role that makes women in a powerless position so that they need to be protected inside the house. With the development of current 
media technology, women are placed as promotional media in ways that are sometimes inappropriate, which of course can invite misinterpretations for those who seen them. The visual form of media promotion has the power to shape perceptions of what we see and can influence behavior and decision to act.

This is different from the presence of the 2018 Tanjung Isuy Festival which was the first festival in Tanjung Isuy, West Kutai (Figure 3). This activity built collective awareness for all young Dayaks regarding the preservation of traditional culture, including the Bawin Dayak. According to the President of the National Dayak Tradition Council A. Teras Narang, Bawin Dayak has a strategic role, the right, authority, and equal role with men in any field of work. They are equal and are seen as individuals who are no different from men, both in the field of work and the right to determine their own opinions. Bawin Dayak deserves a special place to be appreciated and given the widest access to maximize their potential to build the nation [12].
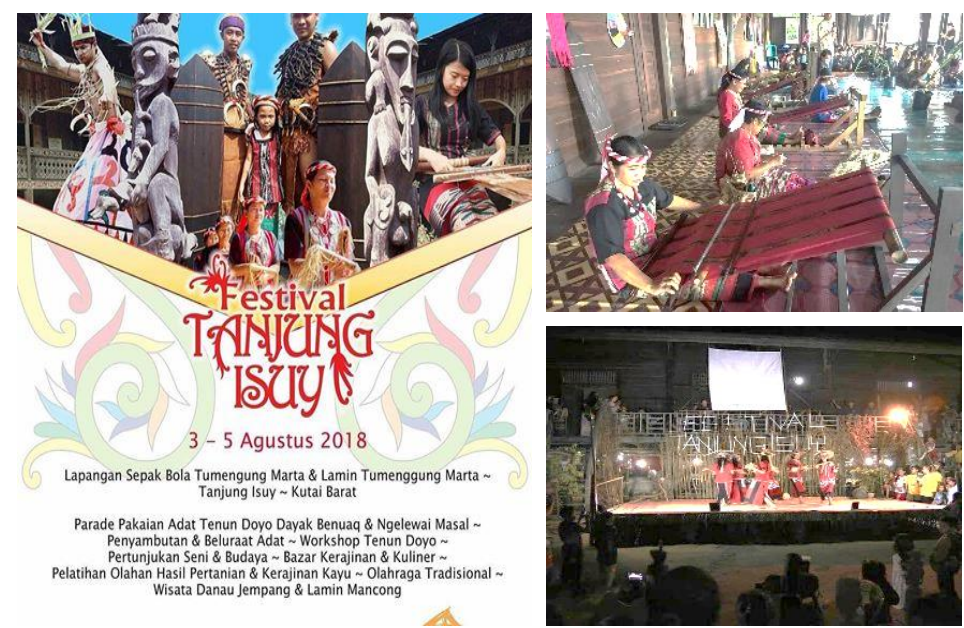

Fig 3. 2018 Tanjung Isuy Festival

In today's development, in the world of youtubers, bloggers and others, it is possible for women to contribute to the promotion of their regions indefinitely, as is done by women who conduct the Tanjung Isuy 2018 festival. Line, whatshap, google, youtube and others make it easy for people to get information. Many people like uploading images or information on Instagram. A lot of good visual information can be searched and discovered. What is done privately, what is preferred and what is currently the center of attention, will easily be found. Even email addresses, cellphone numbers, home addresses, everything about what people like can be traced quickly. A person can become a social media celebrity because he can change his images consistently by uploading photos. Everything that has been shared on social media becomes a public property, it cannot be claimed when others use the data unless it is on privacy settings. However, the media can also be an exaggerated form of art engineering. Images, writings, and videos can be easily changed because there is an editing process. Editing results will affect the perspective and mind of the person who sees it. The intelligence of media features and the responsiveness of technology accelerate the findings that people want to search for or upload. If the uploaded information data has been considered wisely, there can 
be a lot of cultural promotion that has a positive image and can attract visitors to come for cultural tourism purposes.

Women generally like selfies. When a woman becomes a cover on Instagram, random people, whether male or female will click to open it, because it is visually attractive. They see it, make perceptions from different points of view because of different values, morals, experiences, emotions, then make interpretations by commenting directly. Uploading photos or videos should avoid exploiting the body and sensual gestures of women, so that the image of the person who sees it will always be positive. Images with motion in video are more telling than photos. In the video there is a storyline, while an unauthorized photo can make people who see it guess or interpret things that are different, both positive and negative.

Tilita Renata, a native Benuaq Bawin from Tanjung Isuy works at the Community Health Center. She is a cultural performer, dancer, has the skills and techniques to make ulap doyo. She is also an observer, cultural activist, and winner of the Kutai Barat batik design in 2017 held by Dekranasda Kutai Barat. The Tilita Renata community truly cares about cultural preservation. Some of their photos and videos that have been uploaded in instagram have formed a positive interpretation of cultural activities in Tanjung Isuy. Promotion of cultural activities has been wisely informed by Tilita Renata on Instagram, Deskgram.net, and Pinterest. Images without text will cause multi-interpretation, so text is needed to show the importance of images (Bawin Dayak cultural activities). Hashtags have been used for image links or wordcall, that consists of important keywords to call other images. Through social media, working woman is considered a normal phonenomen today and the world also supports this.

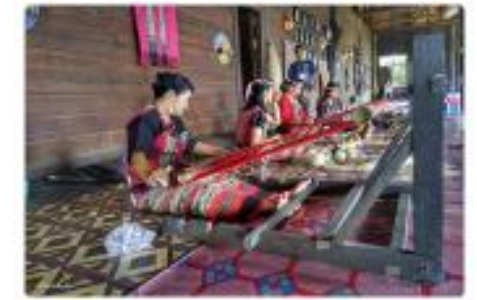

Pengrajn kain tenun khas suku Dsyak Benusq Kabupaten Kutai Barat Ulap Doyo yang dominan lakukan deh kaum perempuan. Loc. Lsmin Tumengung Marta. Kampung Tanjung isuy, Kec. jempane Kab, Kutai Barat, Kalimantan Timur mestivatcanjungisuy Afestwaltanjurgesuy2018 tiamintumenggungmarta ttarjungisuy Adanaujempang vwisatakubar twisacakaition ainfokubar akaltim thubar skutsibsrat - 2 monti (2)
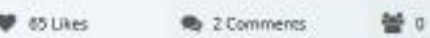

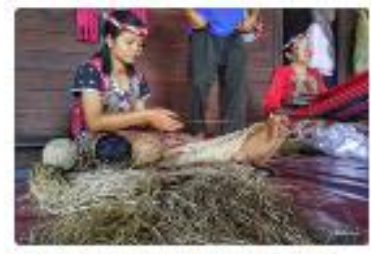

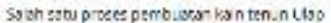

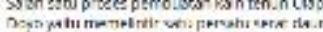

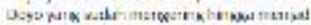

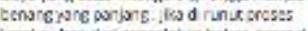

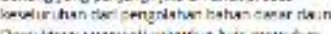

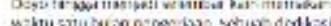

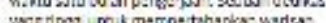

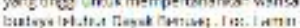

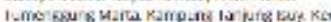

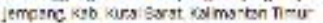

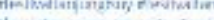

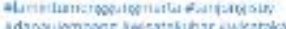

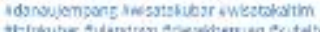

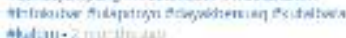

$*$ ?inat

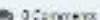

항

Fig 4. A photo uploaded on deskgram.net by Tilita Renata at the 2018 Tanjung Isuy Festival

\section{Conclusion}

Cultural artifacts in the form of lou have undergone decentralization because of the changes in the function of the building from a home for domestic activities to a live museum for touristic activities. The art of tourism that has developed in the inlands of the Benuaq Dayak tribe is an art of acculturation because it is a blend of the skills of local artists / actors with the tastes of tourists. The art of tourism is also a pseudo-traditional art, because the art of 
tourism in general forms still refers to traditional forms, but its sacred and symbolic values have been abandoned. In addition, because the tourists present in an area are only brief, the live performance art (i.e. ulap doyo making activities) is now conducted through a short duration and so it has lost its religious meaning. In addition, lou has also evolved to become a media that is loaded with commercial values, that places the Bawin Dayak women as a cultural charm. The cultural activities of Bawin Dayak should make the activity of ulap doyo become a creative art of the nation, because the process is carried out through perseverance, accuracy, and patience, as well as pride in the preservation of local natural raw materials. There is also a deep spiritual meaning in the process of weaving ulap doyo. Tourism promotion media should display realistic facts from a culture. Submission of information on cultural objects if properly designed can enrich new cultural treasures in the present, and introduce the superiority of Indonesian culture to a global scope. The new media that is developing today can be very useful to introduce local values in the global context.

\section{Acknowledgments}

This research was conducted under the financial support from the Ministry of Research,

Technology and Higher Education of the Republic of Indonesia.

\section{References}

[1] Handriyotopo: Kapita Selekta: Media Budaya Komunikasi Visual. pp.32.ISI Press,Surakarta (2018)

[2] Piliang, Y.A.:Esai Pembuka: Pendekatan dalam Penelitian Desain, Pelbagai Perkembangan Paradigma, dalam John A. Walker, Desain, Sejarah, Budaya: Sebuah Pengantar Komprehensif,Jalasutra, Yogyakarta (2010)

[3] Joshi, Laxman, Kusuma Wijaya, Martua Sirait, Elok Mulyoutami:Indegenous System and Ecological Knowledge Among Dayak People in Kutai Barat, East Kalimantan.ICRAF Southeast Asia Working Paper. pp.2. ICRAF Southeast Asia (2004)

[4] Gunawan, Edy:Melihat Lamin Temenggung Marta di Tanjung Isuy Tertua, Dulu untuk Hindari Penyerangan,Kaltim Post 22 Maret 2013.https://kebudayaan.kemdikbud.go.id/bpcbkaltim/melihat-lamin-temenggungmarta-di-tanjung-isuy-tertua-dulu-untuk-hindari-penyerangan/

[5] Florus, Pulus, dkk:Kebudayaan Dayak: Aktualisasi dan Transformasi, pp.206. PT Grasindo, Jakarta (1994)

[6] Eliade, Mircea.The Sacred and The Propane: The Nature of Religion,translated from the French by Willard R. Trask. New York: Harcourt, Brace \& World, Inc.

[7] http://kaltim.tribunnews.com/2018/07/30/tradisi-tari-sambutan-suku-dayak-benuaqkepada-tamu.

[8] Soedarsono, R.M.: Seni Pertunjukan Indonesia dan Pariwisata, pp.3. arti.line, Bandung (1999)

[9] https://kaltim.antaranews.com/berita/20382/wagub-resmikan-lamin-temenggungmerta-tanjung-isuy.

[10] https://www.indonesiakaya.com/jelajah-indonesia/detail/ulap-doyo-nilai-kearifanlokal-dalam-tenun-warisan-dayak-benuaq).

[11] Kuntjara, Esther: Gender, Bahasa dan Kekuasaan, pp.24-25.Libri,Jakarta (2012)

[12] Riwut, Nila: Bawin Dayak: Kedudukan, Fungsi, dan Peran Perempuan Dayak, pp.17.Galangpress, Yogyakarta(2011) 